\title{
Konsep Diri Suporter Sepak bola Perempuan PSS Sleman
}

\author{
Kevin Orkananda (Correspondence Author) \\ Jurusan Ilmu Komunikasi, Fakultas Ilmu Sosial dan Politik, UPN “Veteran” Yogyakarta, Indonesia \\ orkananda19@gmail.com \\ Raden Muhammad Bathara Poerbaningrat \\ Jurusan Ilmu Komunikasi, Fakultas Ilmu Sosial dan Politik, UPN “Veteran” Yogyakarta, Indonesia \\ batharapoer@gmail.com \\ Submitted: 17 December 2019; Revised: 2 March 2020; Accepted: 2 March 2020
}

\begin{abstract}
Football is the most favorite sport in the society. Football has proven to spark enthusiasm from people who like football, which then create a group or community. One of them is supporter group Brigata Curva Sud which has sub-organizations called Ladies Curva Sud. This research intended to dig self-concept of supporter group that all membered by woman called Ladies Curva Sud. Ladies Curva Sud is a supporter group that has large base and fanaticism for PSS Sleman. This research use qualitative study case method. Data gathered by interview on three interviewee, observation, and literature review. This research finding a self-concept about the supporter group that have behavior, attitude, and identity of Ladies Curva Sud. There are four principles which built Ladies Curva Sud identity: No Politica, Still Solo, Only in Tribunne, and No Leader Just Together.

Keywords: Football Supporter, Identity, Ladies Curva Sud, Self-Concept
\end{abstract}

\begin{abstract}
Abstrak
Sepak bola merupakan cabang olahraga yang paling diminati oleh lapisan besar masyarakat. Sepak bola terbukti dapat memicu antusiasme masyarakat yang menyukai sepak bola, lalu membentuk suatu kelompok atau komunitas. Salah satunya kelompok suporter Brigata Curva Sud yang memiliki sub-organisasi Ladies Curva Sud. Penelitian ini bertujuan untuk menggali konsep diri dari kelompok supporter yang seluruhnya beranggota perempuan yaitu, Ladies Curva Sud. Ladies Curva Sud merupakan kelompok suporter yang memiliki basis massa yang cukup besar dan memiliki sifat fanatisme yang tinggi. Metode penelitian yang digunakan adalah studi kasus dengan teknik wawancara mendalam, observasi, dan studi pustaka. Narasumber dalam penelitian ini berjumlah tiga orang. Berdasarkan hasil penelitian yang diperoleh, peneliti menemukan konsep diri yang membentuk kelompok suporter Ladies Curva Sud serta perilaku, sikap, dan identitas Ladies Curva Sud. Ada empat prinsip dari Ladies Curva Sud yaitu No Politica, Still Solo, Sebatas Pagar Tribun, dan No Leader Just Together yang membentuk identitas mereka.

Kata Kunci: Identitas, Konsep diri, Ladies Curva Sud, Suporter Sepak bola
\end{abstract}

\section{PENDAHULUAN}

Sepak bola merupakan suatu permainan yang dilakukan dengan jalan menyepak dengan tujuan memasukkan bola ke gawang lawan yang mempertahankan gawang tersebut agar tidak kemasukan bola (Muhajir, 2004). Permainan ini menjadi salah satu olahraga yang paling banyak diminati oleh semua kalangan baik anak-anak, dewasa, laki laki dan perempuan. Tidak terbatas usia, kasta kaya atau miskin, semua sering menjadi satu ketika menikmati olahraga ini. Tidak mengherankan, sepak bola dengan secara luar biasa berhasil menempatkan diri sebagai cabang olahraga paling populer di muka bumi, menyisikan cabang olahraga lain yang lebih dulu mapan, seperti atletik dan renang (Junaedi, 2014).

Fenomena perkembangan dunia sepak bola tidak melulu berbicara mengenai permainan tim yang semakin bagus dan persaingan klub yang semakin kompetitif. Kehadiran sekumpulan masyarakat yang rela mengorbankan apa saja demi mendukung klub sepak bola kebanggaannya juga menjadi perbincangan dalam dunia sepak bola. Biasanya seseorang yang menyukai sepak bola sulit untuk beranjak dari layar kaca saat tim favoritnya sedang berlaga, begitu pula bagi mereka yang menonton 
sepak bola secara langsung di dalam stadion. Bahkan, seorang pecinta sepak bola rela untuk membayar berapapun harga tiket masuk tanpa menghiraukan harganya yang mahal ketika ingin menyaksikan tim favoritnya sedang berlaga. Mereka tidak hanya sekedar menonton saja, namun juga melontarkan komentar, meneriakan dukungan untuk tim kesayangan dan terdapat juga teriakan intimidasi untuk tim lawan yang secara otomatis akan menjadi tindakan lanjutan.

Kelompok masyarakat ini biasanya disebut suporter yaitu, sekelompok orang yang memberikan dukungan, sokongan, kepada klub sepak bola yang dibelanya dalam sebuah pertandingan (Alwi, 2005). Keberadaan suporter dalam mendukung klub sepak bola diharapkan dapat meningkatkan mental dan moral bertanding pemain tim yang dibelanya dan sekaligus meneror mental tim lawan. Pada umumnya pendukung tim sepak bola dan sepak bola sendiri saling berkaitan dimana jika terdapat sebuah pertandingan sepak bola secara otomatis akan ada pendukung yang terlibat di dalamnya.

Tidak hanya di negara-negara seperti Inggris, Italia, dan Spanyol yang gemerlap kehidupan suporter terasa. Indonesia juga terasa kental kehidupan sepak bola dengan suporter yang setia pada klub kebanggannya. Hampir sama dengan di luar negeri, di Indonesia setiap klub dari level terendah pasti memiliki penggemar fanatik karena adanya ikatan kedaerahan, keluarga, golongan atau simpatik dengan pemainnya. Meskipun sepak bola dan dunia suporter identik dengan kaum pria, suporter sepak bola tidak hanya didominasi oleh kaum laki-laki tetapi ada juga kaum perempuan di dalamnya. Geliat dunia suporter yang cenderung keras tidak serta merta membuat suporter perempuan menjauhi dunia suporter. Mereka justru menepis hal tersebut dan mencoba berbaur bersama suporter pria lainnya. Adanya fenomena tersebut membuat sepak bola menjadi lebih menarik dimana hampir setiap pertandingan sepak bola semakin sering ditemui kehadiran suporter perempuan dan jumlahnya semakin meningkat dari waktu ke waktu. Indonesia juga memiliki kultur suporter perempuan dalam dunia suporter. Salah satunya pada klub sepak bola yang memiliki basis massa yang besar, yaitu PSS Sleman. Kelompok suporter yang biasa disebut Brigata Curva Sud tersebut memiliki kelompok suborganisasi sendiri dengan sebutan Ladies Curva Sud yang kesemua anggota dan pengurusnya adalah perempuan.

\section{KERANGKA TEORI}

Fenomena kehadiran suporter sepak bola perempuan di Indonesia telah diteliti sebelumnya, yang menemukan bahwa Bonita (bonek wanita) memaknai perannya sebagai suporter kesebelasan Persebaya Kota Surabaya (Novianti, 2014). Penelitian lain menyebutkan adanya relasi antara suporter sepak bola dan media massa, seperti yang terjadi dengan Bonek dan Jawa Pos. Bersamaan dengan melimpahnya pemberitaan tentang Persebaya, Jawa Pos membentuk identitas baru bagi fans Persebaya yang dinamakan Bonek, yang berasal dari akronim Bahasa Jawa "bondho" yang berarti modal dan "nekat" yang berarti nekat. Kata Bonek sendiri muncul dari sebuah berita yang ditulis oleh Slamet Urip Prihadi, wartawan olahraga Jawa Pos (Junaedi, Nugroho, \& Wahyono, 2018).

Dalam penelitian ini, teori yang digunakan adalah teori interaksionisme simbolik. Teori yang dicetuskan George Herbert Mead menyatakan bahwa orang bertindak berdasarkan makna simbolik yang muncul di dalam sebuah situasi tertentu. Makna-makna yang berasal dari interaksi dengan orang lain, terutama dengan orang yang dianggap cukup berarti. Sebagaimana dinyatakan Blumer, bagi seseorang, makna dari sesuatu berasal dari cara-cara orang lain bertindak terhadapnya dalam kaitannya dengan sesuatu. Tindakan-tindakan yang dilakukan akan melahirkan batasan sesuatu bagi orang lain (Poloma, 2007). 


\section{METODE PENELITIAN}

Penelitian menggunakan metode studi kasus. Metode penelitian dilakukan dengan pengumpulan data yang didapat dari wawancara mendalam (in-depth interview), observasi dan studi pustaka. Wawancara mendalam yang dilakukan secara terencana dan terstruktur dengan narasumber. Pertanyaan disusun dengan jenis interview guide, dimana yang paling signifikan dalam wawancara mendalam adalah mengajukan pertanyaan yang ada di panduan wawancara (interview guide) dan mengembangkannya ke dalam berbagai pertanyaan serta kemudian mencatat jawaban narasumber atas pertanyaan yang diajukan secara akurat (Neuman, 2013).

Pemilihan narasumber menggunakan purposive sampling atau criterion-based selection. Kriteria yang digunakan adalah narasumber merupakan pengurus struktural dari Ladies Curva Sud dan orang yang tergabung sejak awal berdirinya Ladies Curva Sud. Narasumber dalam penelitian ini adalah Widy Kurniawan, Pramudita Anggraeni, dan Olivia Sausan. Kemudian, observasi yang dilakukan oleh peneliti menggunakan cara pengamatan yang mendalam tentang aktivitas dan lingkungan di sekitar narasumber yaitu di Stadion Maguwoharjo dan Sekretariat Brigata Curva Sud di Jalan Delima no 25, Condong Catur, Sleman, Yogyakarta. Setelah data terkumpul akan dilakukan reduksi, analisis dan sajian data. Reduksi data dalam penelitian ini merupakan bagian proses seleksi, pemfokusan, penyederhanaan dan abstraksi data dari transkrip wawancara mendalam dan fieldnote.

\section{HASIL DAN PEMBAHASAN}

Ladies Curva Sud merupakan sekumpulan pendukung atau suporter sepak bola dari klub PSS Sleman yang menjadi sub-organisasi dari Brigata Curva Sud. suporter Ladies Curva Sud yang menjadi bagian Brigata Curva Sud terkenal dengan sikap sportif dan aksi-aksi yang begitu fanatik dalam mendukung tim kesebelasannya bertanding. Tindakan yang dilakukan oleh Ladies Curva Sud berpandangan seperti apa yang ditampilkan oleh kultur ultras seperti penggunaan pakaian serba hitam, menggunakan buff ataupun slayer di wajah sebagai perwujudan "No Name No Face. Selain itu, penggunaan atribut seperti giant flag, hand banner, dan juga syal saat mendukung PSS Sleman berlaga juga identik dengan kultur suporter ultras.

Dalam dukungan secara langsung, Ladies Curva Sud juga memberikan dukungan berupa nyanyian, gerakan, sorakan, dan tepukan secara massal saat mendukung PSS Sleman berlaga, sesuatu hal baru bagi dunia suporter di Indonesia. Lirik dan nada yang digunakan oleh kelompok suporter Ladies Curva Sud juga terinspirasi dari sejumlah kelompok suporter yang menggunakan ideologi ultras, seperti suporter Radja Casablanca dan Yokohama F. Marinos.

Suporter Ladies Curva Sud memang dikenal sebagai salah satu suporter yang fanatik dan memiliki bassis massa yang besar. Fanatisme yang dimiliki oleh kelompok suporter Ladies Curva Sud timbul dari manifesto yang mereka miliki. Manifesto adalah sebuah dasar ideologi dalam bertindak yang dimiliki oleh Ladies Curva Sud. Melalui manifesto tersebut, munculah tindakan fanatisme dari Ladies Curva Sud. Tindakan fanatisme tersebut sebagai sebuah bentuk penafsiran akan kontruksi yang telah dibangun dalam kelompok Ladies Curva Sud. Tindakan tersebut dilakukan secara kolektif berdasarkan penafsiran dan pertimbangan individu ataupun kelompok kecil yang ada di dalamnya.

Tindakan fanatisme yang muncul pada Ladies Curva Sud adalah budaya awaydays yang cukup mengakar kuat dari para anggotanya. Berawal dari manifesto Ladies Curva Sud yang memberlakukan awaydays sebagai sesuatu yang sakral bagi kelompok suporter tersebut, maka awaydays atau mendukung PSS Sleman hingga ke kandang lawan menjadi hal yang wajib dilakukan oleh Ladies Curva Sud. Bentuk fanatisme lain yang dimunculkan oleh Ladies Curva Sud adalah budaya membeli tiket untuk menonton pertandingan PSS Sleman. Keadaan ini mengartikan bahwa apabila anggota dari Ladies Curva Sud 
tidak memiliki tiket maka tidak dapat menyaksikan PSS Sleman berlaga. Sama seperti Awaydays, gerakan ini terinspirasi dari manifesto atau dasar ideologi Ladies Curva Sud yaitu, No Ticket No Game.

Hal unik lain dari Ladies Curva Sud dalam fanatisme yang dilakukannya adalah Mandiri Menghidupi. Selain mendukung dengan nyanyian dan gerakan secara kompak di tribun. Kelompok suporter ini juga membantu finansial dari PSS Sleman dengan menyumbangkan separuh hasil keuntungan merchandise mereka untuk keberlangsungan tim kebanggan mereka, PSS Sleman. Kelompok Ladies Curva Sud terdiri dari orang-orang yang saling berinteraksi dan berbagi nilai, norma, dan harapan yang sama di dalamnya. Sebagaimana kelas sosial, status, dan peran mempengaruhi tindakan apa yang akan kita lakukan. Menjadi bagian dari Ladies Curva Sud berarti menyerahkan kepada kelompok untuk mengambil keputusan tertentu mengenai sikap kita. Anggota dari Ladies Curva Sud mengasumsikan adanya suatu kewajiban untuk bertindak sesuai dengan harapan anggota lain dalam kelompok tersebut. Harapan tersebut tercermin dalam manifesto yang dimiliki oleh Ladies Curva Sud yang membuat Ladies Curva Sud bersikap seperti apa yang ada di dalam manifesto yang mereka miliki.

Berikut ini adalah sikap yang ditunjukkan oleh Ladies Curva Sud dalam mendukung PSS Sleman. Peneliti membagi sikap yang ditonjolkan menjadi tiga yaitu, No Politica, Still Solo, Sebatas Pagar Tribun, No Leader Just Together. Dari wawancara yang peneliti lakukan dengan tiga narasumber. Peneliti menyimpulkan bahwa Ladies Curva Sud memiliki sikap No Politica. Sikap ini dimaksudkan untuk menghindari keterlibatan berpolitik dari para anggotanya, terlebih lagi jika membawa nuansa politik kedalam tribun selatan. Sebuah tribun dimana Ladies Curva Sud memberikan dukungan terhadap PSS Sleman. Namun, Ladies Curva Sud tidak melarang setiap anggotanya untuk memberikan hak politiknya.

Sikap selanjutnya yang ditunjukan oleh Ladies Curva Sud adalah Still Solo. Mereka menyatakan bahwa tidak berpihak terhadap kelompok suporter manapun. Mereka berasaskan kepada gerakan "nonblock", terbuka kepada siapapun, menjunjung tinggi rasa hormat terhadap sesama kelompok yang memiliki visi misi yang sama, dan yang utama adalah fokus sepenuhnya dalam mendukung PSS Sleman. Sebatas Pagar Tribun adalah sikap dari Ladies Curva Sud untuk menghindari keterlibatan lebih dan intervensi terhadap klub PSS Sleman. Mereka membatasi campur tangan pada manajemen dan tetap mendukung PSS Sleman sebatas berada di tribun, dan menjadikan pagar sebagai batasan mereka.

Sebelum memberikan makna atas sesuatu, terlebih dahulu aktor melakukan serangkaian kegiatan olah mental: memilih, memeriksa, mengelompokkan, membandingkan, memprediksi, dan mentransformasi makna dalam kaitannya dengan situasi, posisi, dan arah tindakannya. Begitu juga yang dialami oleh kelompok suporter Ladies Curva Sud, sekumpulan pendukung atau suporter sepak bola dari klub PSS Sleman yang menjadi sub-organisasi dari Brigata Curva Sud. Suporter Ladies Curva Sud yang menjadi bagian dari Brigata Curva Sud. Aksi yang ditampilkan oleh Ladies Curva Sud dalam mendukung PSS Sleman menggunakan kultur suporter Italia atau lebih dikenal dengan sebutan ultras. Pemaknaan sebagai seorang suporter yang berkiblat pada suporter Italia atau ultras membuat mereka bertindak seperti ultras Italia. Mulai dari cara berpakaian yang hampir sama dengan ultras Italia ataupun lagu-lagu yang biasa dinyanyikan saat mendukung tim kebanggannya berlaga juga diaopsi dari kultur suporter Italia.

Interaksi simbolik merujuk pada karakter interaksi yang berlangsung antar manusia. Setiap orang tidak hanya bereaksi terhadap tindakan yang lain tetapi juga menafsirkan dan mendefinisikan setiap tindakan orang orang lain. Respon orang tersebut baik secara langsung maupun tidak langsung didasarkan atas penilaian makna. Oleh karenanya, interaksi manusia dijembatani oleh penggunaan simbol-simbol penafsiran atau dengan menemukan makna tindakan orang lain (Zeitlin, 1995). 
Pokok-pokok premis pendekatan interaksi simbolik adalah masyarakat terdiri dari individu-individu yang memiliki kedirian mereka sendiri (yakni membuat indikasi untuk dirinya sendiri). Tindakan individu itu merupakan suatu konstruksi dan bukan sesuatu yang lepas begitu saja, yakni keberadaannya dibangun oleh individu melalui penafsiran situasi di mana dia bertindak, sehingga kelompok atau tindakan kolektif itu sendiri dari beberapa susunan tindakan beberapa individu, yang disebabkan oleh penafsiran individu atau pertimbangan individu terhadap tindakan yang lainnya (Zeitlin, 1995). Sebagai sebuah kelompok suporter, Ladies Curva Sud memang dikenal sebagai salah satu suporter yang fanatik dan memiliki bassis massa yang besar. Tindakan fanatisme yang dilakukan oleh Ladies Curva Sud memiliki peranan penting dalam keberlangsungan mereka. Baik untuk pemberi semangat bagi tim kebanggaanya, maupun bagi keberlangsungan keberadaan Ladies Curva Sud sendiri. Selain itu, meskipun tingkat fanatisme mereka cukup tinggi, sikap sportif dalam mendukung klub kebanggaan tetap ditunjukkan oleh kelompok suporter Ladies Curva Sud.

Tindakan melibatkan pilihan antara cara-cara mencapai tujuan-tujuan dalam situasi baik mengenai objek fisik maupun sosial. Termasuk didalamnya norma-norma sosial dan nilai-nilai kultural. Proses institusionalisasi atau pelembagaan mencakup pelaku-pelaku yang menyesuaikan tindakan-tindakan mereka satu sama lain dan memberikan kepuasan timbal-balik yang akan berkembang menjadi suatu pola mengenai status peranan dan struktur peran. Hal ini dilihat dalam hubungannya dengan harapanharapan yang dimiliki orang-orang dalam berhubungan satu sama lain. Kenyataannya dunia terbentuk oleh kontak-kontak lisan (percakapan-percakapan), baik yang bersifat internal maupun eksternal (Craib, 1986). Kelompok (group) terdiri dari orang-orang yang saling berinteraksi dan berbagi nilai, norma, dan harapan yang sama. Sebagaimana kelas sosial, status, dan peran kita mempengaruhi tindakan yang akan kita lakukan. Kelompok di mana kita bergabung pun merupakan kekuatan yang tangguh dalam kehidupan. Menjadi bagian suatu kelompok berarti menyerahkan kepada orang lain hak untuk mengambil keputusan tertentu mengenai perilaku kita. Kita menjadi bagian suatu kelompok, maka kita mengasumsikan adanya suatu kewajiban untuk bertindak sesuai dengan harapan anggota lain dalam kelompok tersebut (Henslin, 2007).

\section{KESIMPULAN}

Berdasarkan temuan dalam penelitian, dapat disimpulkan bahwa kelompok supporter Ladies Curva Sud merupakan sub-organisasi dari Brigata Curva Sud. Sikap sportif dan fanatisme dalam sepak bola melekat dalam identitas kelompok Ladies Curva Sud sendiri. Identitas kelompok Ladies Curva Sud mengadopsi dari gaya ultras Italia dan penggunaan atribut serta hitam yang diperkuat oleh persepsi yang sama tentang simbol verbal dan nonverbal. Dalam pembentukan identitas ini, mereka dipengaruhi juga oleh particular other dan generalized other (society).

Ladies Curva Sud memiliki basis massa yang cukup besar dan dikenal fanatik. Budaya awaydays yang melekat dalam kelompok supporter tersebut juga budaya membeli tiket pertandingan adalah beberapa hal kecil fanatisme mereka. Kelompok supporter ini juga mempunyai hal yang unik dalam fanatismenya, yaitu mereka juga membantu finansial tim PSS Sleman dengan menyumbangkan separuh hasil merchandise-nya untuk keberlangsungan tim PSS Sleman. Sikap yang hadir dari diri mereka ketika menyaksikan PSS Sleman dikategorikan menjadi tiga sikap, yaitu, No Politica, Still Solo, Sebatas Pagar Tribun. No Leader Just Together.

\section{REFERENSI}

Alwi, H. (2005). Kamus Besar Bahasa Indonesia Edisi Ketiga. Jakarta: Balai Pustaka.

Craib. (1986). Teori-teori Sosial Modern dari Parsons Sampai Habermas. Jakarta: Rajawali.

Henslin, J. M. (2007). Sosiologi dengan Pendekatan Membumi. Jakarta: Erlangga. 
Junaedi, F. (2014). Merayakan Sepak Bola: Fans, Identitas dan Media. Yogyakarta: Buku Litera.

Junaedi, F., Nugroho, H., \& Wahyono, S. (2018). Komodifikasi Bonek dalam Jejaring Konglomerasi Jawa Pos. Jurnal ASPIKOM, 3(5), 891-902 doi:http://dx.doi.org/10.24329/aspikom.v3i5.303

Muhajir. (2004). Pendidikan Jasmani Teori dan Kesehatan. Bandung: Angkasa.

Neuman, W. L. (2013). Metodologi Penelitian Sosial Pendekatan Kualitatif dan Kuantitatif Edisi 7. Jakarta: Indeks .

Novianti. (2014). Bonita; Studi Deskriptif tentang Makna Bonek Wanita Sebagai Suporter Persebaya. Jurnal Komunikasi, 18-20.

Poloma, M. M. (2007). Sosiologi Kontemporer. Jakarta: Rajawali Grafindo.

Zeitlin, M. I. (1995). Memahami Kembali Sosiologi. Yogyakarta: Gajah Mada. 